九州大学学術情報リポジトリ

Kyushu University Institutional Repository

\title{
Culture Conditions of Psychrotrophic Fungus, Penicillium chrysogenum and Its Lipase Characteristics
}

Cho, Hee-Yeon

Keck School of Medicine, University of Soutern California

Bsncerz, Renata

Department of Biochemistry, Marie Curie-Sklodowska University

Ginalska, Grazyna

Department of Biochemistry, Marie Curie-Sklodowska University

Leonowicz, Andrzej

Department of Biochemistry, Marie Curie-Sklodowska University

他

https://doi.org/10.5109/9315

出版情報: 九州大学大学院農学研究院紀要. 52 (2)，pp.281-286，2007-10-29. Faculty of Agriculture, Kyushu University

バージョン :

権利関係 : 


\title{
Culture Conditions of Psychrotrophic Fungus, Penicillium chrysogenum and Its Lipase Characteristics
}

\author{
Hee-Yeon CHO $^{1}$, Renata BANCERZ ${ }^{2}$, Grazyna GINALSKA ${ }^{2}$, Andrzej LEONOWICZ ${ }^{2}$, \\ Nam-Seok $\mathrm{CHO}^{3}$ and Shoji OHGA*
}

\author{
Laboratory of Forest Resources Management, Division of Forest Ecosphere Management, \\ Department of Forest and Forest Products Sciences, Kyushu University, \\ Sasaguri, Fukuoka 811-2415, Japan \\ (Received May 15, 2007 and accepted July 17, 2007)
}

\begin{abstract}
Among 97 fungal strains from the soil collected from the high mountain areas in the Jeju Island, Korea, Penicillium chrysogenum 9 was found to be the best lipase producer. Its lipase productivity reached 42 $\mathrm{U} / \mathrm{ml}$ in the culture medium. Factors affecting lipase production by Penicillium chrysogenum 9 were studied using fermentation media of different chemical compositions. Under optimal conditions we noted a 1.6-fold increase of lipase activity. The maximum lipase activity was $68 \mathrm{U} / \mathrm{ml}$ of culture medium on the 5 th day of incubation at $\mathrm{pH} 6.0$ and $20^{\circ} \mathrm{C}$; therefore, Penicillium chrysogenum 9 was classified as a psychrotrophic microorganism. The enzyme from Penicillium chrysogenum 9 showed a maximum activity at $30^{\circ} \mathrm{C}$ and $\mathrm{pH} 5.0$ for synthetic substrates (triacylglycerols) or at pH 7.0 for natural substrates (oils).
\end{abstract}

\section{INTRODUCTION}

Lipases (triacylglycerol acylhydrolase EC 3.1.1.3.) are enzymes that catalyze the hydrolysis of fats and mono- and di-glycerides to free fatty acids and glycerol but are also unique serine esterases which catalytic activity is significantly enhanced at the liquid water interface. Although lipases have been found in many species of animals and plants, the enzymes from microbial sources (such as bacteria, yeast and fungi) are currently receiving particular attention because of their actual and potential applications in industry mainly in the detergents, oils and fats, dairy and pharmaceutical industries (Sarkar et al., 1998; Costa and Peralta, 1999; Cardenas et al., 2001).

Enzymes from extremophiles are valuable objects of research of biotechnologists from the point of view of their widest capabilities of technological utilization. Among enzymes from cold-adapted microorganisms, lipases and proteases have a considerable potential, mainly in the food industry and as additives to detergents. Specificity of lipases provides numerous applications such as flavour-modifying enzymes, detergent additives or stereospecific catalysts (Feller et al., 1991). Microorganisms living in extreme environments have adapted to their habitats in such a way that metabolic process permits them to survive and function (Prins et al., 1990).

All microorganisms have a characteristic optimal growth temperature at which they exhibit their highest growth and a range of temperatures they can tolerate.

${ }^{1}$ Molecular Microbiology and Immunology, Keck School of Medicine, University of Southern California, Los Angeles, CA 90089, USA

${ }^{2}$ Department of Biochemistry, Marie Curie-Sklodowska University, Lublin 20-031, Poland

${ }^{3}$ School of Forest Resources and Rural Engineering, Chungbuk National University, Cheongju 361-763, Korea

* Corresponding author (E-mail: ohga@forest.kyushu-u. ac.jp)
Psychrophilic microorganisms have been defined as organisms, which have optimal growth temperature below $16{ }^{\circ} \mathrm{C}$ and an upper temperature limit of $20^{\circ} \mathrm{C}$, and psychrotrophic microorganisms, which are able to divide at $0{ }^{\circ} \mathrm{C}$ and grow optimally at temperatures around $20-25^{\circ} \mathrm{C}$. High microbial growth rates as well as high enzymatic activities and catalytic efficiencies in the temperature range of $0-20^{\circ} \mathrm{C}$ of cold-adapted microorganisms (at which homologous mesophilic enzymes are not active) prevent the risk of microbial contamination (Margesin and Schinner, 1994). Enzymes from psychrophils and psychrotrophs may require even shorter reaction times as compared to mesophilic enzymes used near their low temperature limit (Ludlow and Clark, 1991).

The present paper deals with the screening of lipase producing psychrotrophic strains isolated from the cold high mountain area, culture conditions for the enzyme production by the selected strain and some properties of the enzyme that are important for its industrial application.

\section{MATERIALS AND METHODS}

\section{Microorganisms}

Fungi were isolated from soils of the high Mt. Halla areas in the Jeju Island situated in southern part of Korea. Compositions of Martin medium used for screening of microorganisms were as follows: glucose, 1\%; peptone, $0.5 \% ; \mathrm{K}_{2} \mathrm{HPO}_{4}, 0.1 \%$; $\mathrm{MgSO}_{4} \mathrm{x} 7 \mathrm{H}_{2} \mathrm{O}, 0.05 \%$; rose bangal (sterilized separately) $0.003 \%$. After sterilization $0.003 \%$ of streptomycin was added.

\section{Isolation of microorganisms from soil}

Isolation of microorganisms was completed by means of a dilution plate method. Portions of $1.0 \mathrm{~g}$ of representative soil were placed in a dilution tube containing $9 \mathrm{ml}$ of sterile distilled water, and shaken for 60 min. Serial 10-fold dilutions were made and surface 
inoculated onto agar plates of Martin medium plates were incubated for $8-10$ days at 15 and $30^{\circ} \mathrm{C}$. Fungi were isolated from plates that contained no more than 50 well-separated colonies.

\section{Taxonomic characterization of fungi}

Identification of isolated moulds strains was achieved on the basis of their micro- and macro-morphological features, expressed in microcultures, and on agar plates containing known diagnostic media for moulds, by the method of Domsch et al. (1980) and Onions and Brady (1987).

\section{Preliminary selection of strains for lipase activity}

The first selection of lipase active strains was done on the basis of the magnitude diffusion zone of the enzyme (mm, in diameter) secreted into agar medium by growing colonies. As similar diffusion technique alternately used for lipase formed by culture, supernatants were added to agar plates $(2 \%, 20 \mathrm{ml})$ containing in $0.1 \mathrm{M}$ phosphate buffer ( $\mathrm{pH} 7.0$ ) and $1 \%$ tributyrin. In this approach, the liquids $(0.3 \mathrm{ml})$ were dropped into a well (10 $\mathrm{mm}$ diameter) previously cut out in agar medium. During the enzymatic reaction (96 h at $28^{\circ} \mathrm{C}$ ) the clear zones were formed.

\section{Growth media and culture conditions}

Seven different media were used for optimization:

- GPN - glucose 1\%; peptone 5\%; $\mathrm{NaNO}_{3} 0.1 \% ; \mathrm{KH}_{2} \mathrm{PO}_{4}$

$0.1 \% ; \mathrm{MgSO}_{4} \times 7 \mathrm{H}_{2} \mathrm{O} 0.05 \%$; olive oil $1 \%$.

- PEK - peptone 5\%; yeast extract $1 \%$; $\mathrm{KH}_{2} \mathrm{PO}_{4} 1.4 \%$;

$\mathrm{Na}_{2} \mathrm{PO}_{4} 0.24 \% ; \mathrm{MgSO}_{4} \mathrm{x} 7 \mathrm{H}_{2} \mathrm{O} 0.04 \%$; olive oil $1 \%$.

- GKM - glucose $1 \%$; $\mathrm{KH}_{2} \mathrm{PO}_{4} 0.6 \%$; $\mathrm{MgSO}_{4} \mathrm{x} 7 \mathrm{H}_{2} \mathrm{O} 0.1 \%$; urea $0.4 \%$. Micronutrients: $\mathrm{FeCl}_{3} \times 6 \mathrm{H}_{2} \mathrm{O} \quad 0.001 \%$; biotin; thiamin $\mathrm{HCl}$; inositol; olive oil $1 \%$.

- EKM - yeast extract $0.5 \% ; \mathrm{KH}_{2} \mathrm{PO}_{4} 1 \% ; \mathrm{MgSO}_{4} \mathrm{x} 7 \mathrm{H}_{2} \mathrm{O}$ $0.1 \%$; olive oil $1 \%$.

- NKM - $\mathrm{NaH}_{2} \mathrm{PO}_{4} 1.2 \% ; \mathrm{KH}_{2} \mathrm{PO}_{4} 0.2 \% ; \mathrm{MgSO}_{4} \times 7 \mathrm{H}_{2} \mathrm{O}$ $0.03 \% ; \mathrm{CaCl}_{2}$ 0.03\%; olive oil $1 \%$.

- PKK - peptone $1 \% ; \mathrm{KH}_{2} \mathrm{PO}_{4} 1.4 \% ; \mathrm{K}_{2} \mathrm{HPO}_{4} 0.24 \%$; $\mathrm{MgSO}_{4} \times 7 \mathrm{H}_{2} \mathrm{O} 0.04 \%$; olive oil $1 \%$.

- SKN - starch 0.1\%; $\mathrm{KH}_{2} \mathrm{PO}_{4} 0.2 \% ; \mathrm{NH}_{4} \mathrm{NO}_{3} 0.1 \%$; $\mathrm{MgSO}_{4} \times 7 \mathrm{H}_{2} \mathrm{O} 0.1 \%$; olive oil $1 \%$.

Initial pH was adjusted to 6.0 or 7.0. The media were autoclaved at $121^{\circ} \mathrm{C}(15 \mathrm{psi})$ for $25 \mathrm{~min}$. The flasks containing $25 \mathrm{ml}$ of medium were inoculated with $2 \mathrm{ml}$ spore suspensions (about $2 \times 10^{6}$ spores) and cultured for 5 days at $20^{\circ} \mathrm{C}$ on a rotary shaker operating at $150 \mathrm{rpm}$.

\section{Analytical procedure}

The mycelium was separated by filtration through Miracloth quick filtration material (Chicopee Mills, Inc., New York, USA) and centrifuged at 10,000 rpm for $15 \mathrm{~min}$ at $4^{\circ} \mathrm{C}$. The supernatant was used as the crude enzyme for the estimation of lipase activity. Lipase activity was determined by the method of Sokolovska et al. (1998). One unit (U) of lipase activity is defined as the amount of enzyme releasing $1 \mu \mathrm{mol}$ of free fatty acids per minute under assay conditions. Protein con- centration was estimated by the method of Lowry et al. (1951) with bovine serum albumin as a standard. Biomass was determined by estimation of dry weight of the mycelium by washing and drying the sample at $105^{\circ} \mathrm{C}$ for $24 \mathrm{~h}$. Cultivations were performed in 3 replicate culture flasks, and analysis carried out in duplicate. The data given here are the means of the measurements. The mean standard error of the enzyme estimate was \pm 0.23 and ranged from \pm 0.003 to $\pm 0.32 \mathrm{U} / \mathrm{ml}$.

\section{Effect of different parameters on lipase produc- tion}

Various parameters were studied in order to achieve maximum lipase production from Penicillium chrysogenum 9 .

a. Effect of inducers at a concentration of $1 \%$ - fatty acids (oleic and caprylic acid), triglycerides (tributyrin, tricaprylin, triolein) and different oils, such as olive, corn, soybean and rape.

b. Effect of carbon sources (sugar) at a concentration of $1 \%$ : monosaccharides (fructose, galactose, xylose and glucose), disaccharides (sucrose, maltose and lactose) and polysaccharide (starch).

c. Effect of various nitrogen sources: organic nitrogen sources (yeast extract, peptone, casein, asparagine and urea), inorganic nitrogen sources (ammonium nitrate, sodium nitrate and diammonium hydrogen orthophosphate).

d. Effect of initial culture $\mathrm{pH}: \mathrm{pH}$ of the medium varied from 3.0 to 11.0 .

\section{RESULTS AND DISCUSSION}

All 97 strains isolated from soil samples in preliminary experiments were tested to determine their lipolytic activity by employing screening techniques on agar plates, containing 1\% tributyrin as substrate.

For forty-seven fungal strains smaller or bigger halozones (14-27 mm) were observed around circular wells with culture supernatant. Nine strains showed a big zone above $18 \mathrm{~mm}$. The results are summarized in Table 1. Out of 9 microorganisms, two strains, Penicillium chrysogenum 9 and Cladosporium

Table 1. Preliminary evaluation of lipase activity of moulds grown in on basal medium. Relative activity was expressed in mm of enzymatic zone size formed on agar plates

\begin{tabular}{lcc}
\hline \multicolumn{1}{c}{ Organisms } & $\begin{array}{c}\text { Number of } \\
\text { strains tested }\end{array}$ & $\begin{array}{c}\text { Lipase } \\
\text { activity (mm) }\end{array}$ \\
\hline Cladosporium cladosporoides & 16 & 23 \\
Penicillium chrysogenum & 9 & 21 \\
Cylindrocarpon magnusianum & 40 & 20 \\
Aspergillus versicolor (Vull.) & 16 & 20 \\
Cladosporium cladosporoides & 43 & 19 \\
Chrysosporium pannorum & 24 & 18 \\
Penicillium lanosum & 29 & 18 \\
Chrysosporium pannorum & 53 & 18 \\
Chrysosporium pannorum & 57 & 18 \\
\hline
\end{tabular}


cladosporoides 16, were found to produce high activity of extracellular lipase, as they showed the biggest clear zone (diameter over $21 \mathrm{~mm}$ ). Since the isolates were obtained from representative samples in the environment, we can presume that lipase-producing microorganisms are well distributed in the cold mountain area soil.

Seven media with different constituents were tested to maximize lipase production by the selected strains $P$. chrysogenum and $C$. cladosporoides. The initial pH of the media was adjusted to $\mathrm{pH} 6.0$ or 7.0. Fungal biomasses and lipolytical activities of both strains were estimated and compared in 5-day cultures. Table 2 shows the medium GKM of $\mathrm{pH} 6.0$ to be the best for lipase production by microorganisms used in this study. Consequently, only Penicillium chrysogenum was selected for further studies because it produced the highest level of lipase activity (42 U/ml).

Lipolytic enzyme production by microorganisms depends mainly on the incubation conditions and the composition of the media. Penicillium chrysogenum growth on GKM medium was performed for seven days under the conditions given in Materials and Methods, and at a temperature varying from $10^{\circ} \mathrm{C}$ to $30^{\circ} \mathrm{C}$. The aim of this experiment was to establish the influence of temperature and time of cultivation on fungal biomass increase and lipolytical activity level in P. chrysogenum. Hence, it was possible to determine what kind of extremophile this fungal strain was. The results summarized in Table 3 show that $P$. chrysogenum grows well at temperatures of $10-25^{\circ} \mathrm{C}$, which was testified by the level of dry fungal mass. The maximum amounts of fungal mycela were observed on the 7 th day of culture at $10^{\circ} \mathrm{C}$, and the 5 th day at $20^{\circ} \mathrm{C}$. When performing the culture at $30^{\circ} \mathrm{C}$, the increase in mycelium dry weight was minimal. Simultaneously the lipolytic activity in culture filtrates was estimated. The maximum lipase activity was obtained on the 5th day of incubation at $20^{\circ} \mathrm{C}(40 \mathrm{U} / \mathrm{ml})$, which was accompanied by an increase in mycelium dry weight. A low lipase activity was observed when $P$. chrysogenum was incubated at $10^{\circ} \mathrm{C}$ (about $10 \mathrm{U} / \mathrm{ml}$ ). A similar result was reported for Penicillum citrinum (Maliszewska and Mastalerz, 1992) incubated at $22^{\circ} \mathrm{C}$. Psychrotrophic fungi of the genus Penicillium were also isolated from the softwood in Sweden by Land et al. (1987).

In further experiments, the lipase activity under different growth conditions was tested on the 5th day of incubation. Different lipidic substrates (fatty acids, triacylglycerols and oils) were tested as activators for lipase production. As shown in Table 4, among few lipids used in the experiment, corn oil appeared to be the best substrate for lipase production. The activity of lipase synthesized under these conditions was of $55 \mathrm{U} / \mathrm{ml}$. Still, Penicillium chrysogenum presented a high lipolytic activity when incubated with triolein, olive oil and oleic acid. Studies on varying concentrations of corn oil in the culture medium showed lipase production to improve to $55 \mathrm{U} / \mathrm{ml}$, when using $1 \%$ corn oil (data not shown). Lipolytic activity decreased dramatically when higher concentrations of corn oil were added to GKM medium. This is similar to a report on lipase production

Table 2. Comparison of biomass and lipase activity from P. chrysogenum 9 and C. cladosporoides 16 measured in different culture media

\begin{tabular}{|c|c|c|c|c|c|c|c|c|}
\hline \multirow{3}{*}{$\begin{array}{l}\text { Culture } \\
\text { media }\end{array}$} & \multicolumn{4}{|c|}{ Penicillium chrysogenum } & \multicolumn{4}{|c|}{ Cladosporium cladosporoides } \\
\hline & \multicolumn{2}{|c|}{ pH 6.0} & \multicolumn{2}{|c|}{ pH 7.0} & \multicolumn{2}{|c|}{$\mathrm{pH} 6.0$} & \multicolumn{2}{|c|}{ pH 7.0} \\
\hline & $\begin{array}{c}\text { Activity } \\
\mathrm{U} / \mathrm{ml}\end{array}$ & $\begin{array}{c}\text { Biomass } \\
\mathrm{g} / \mathrm{l}\end{array}$ & $\begin{array}{c}\text { Activity } \\
\text { U/ml }\end{array}$ & $\begin{array}{c}\text { Biomass } \\
\mathrm{g} / \mathrm{l}\end{array}$ & $\begin{array}{c}\text { Activity } \\
\text { U/ml }\end{array}$ & $\begin{array}{c}\text { Biomass } \\
\mathrm{g} / \mathrm{l}\end{array}$ & $\begin{array}{c}\text { Activity } \\
\mathrm{U} / \mathrm{ml}\end{array}$ & $\begin{array}{c}\text { Biomass } \\
\mathrm{g} / \mathrm{l}\end{array}$ \\
\hline SKN & 0 & 6.4 & 0 & 4.4 & 10 & 5.2 & 5 & 4.8 \\
\hline GKM & 42 & 11.6 & 0 & 12.8 & 22 & 32.0 & 5 & 11.6 \\
\hline PEK & 0 & 35.6 & 16 & 26.0 & 0 & 22.8 & 0 & 21.6 \\
\hline GPN & 31 & 32.8 & 0 & 11.6 & 0 & 24.0 & 2 & 24.0 \\
\hline EKM & 0 & 10.4 & 0 & 10.8 & 0 & 11.6 & 0 & 15.6 \\
\hline NKM & 0 & 0.8 & 2 & 0.48 & 0 & 4.0 & 0 & 1.12 \\
\hline PKK & 12 & 14.0 & 0 & 13.2 & 1 & 17.2 & 3 & 11.2 \\
\hline
\end{tabular}

Table 3. Effect of growth temperature and incubation time on lipase activity

\begin{tabular}{|c|c|c|c|c|c|c|c|c|}
\hline \multirow{3}{*}{$\begin{array}{c}\text { Day of } \\
\text { incubation }\end{array}$} & \multicolumn{8}{|c|}{ Growth Temperature } \\
\hline & \multicolumn{2}{|c|}{$10^{\circ} \mathrm{C}$} & \multicolumn{2}{|c|}{$20^{\circ} \mathrm{C}$} & \multicolumn{2}{|c|}{$25^{\circ} \mathrm{C}$} & \multicolumn{2}{|c|}{$30^{\circ} \mathrm{C}$} \\
\hline & $\begin{array}{l}\text { Activity } \\
\mathrm{U} / \mathrm{ml}\end{array}$ & $\begin{array}{c}\text { Biomass } \\
\mathrm{g} / \mathrm{l}\end{array}$ & $\begin{array}{c}\text { Activity } \\
\text { U/ml }\end{array}$ & $\begin{array}{c}\text { Biomass } \\
\mathrm{g} / \mathrm{l}\end{array}$ & $\begin{array}{c}\text { Activity } \\
\text { U/ml }\end{array}$ & $\begin{array}{c}\text { Biomass } \\
\mathrm{g} / 1\end{array}$ & $\begin{array}{l}\text { Activity } \\
\mathrm{U} / \mathrm{ml}\end{array}$ & $\begin{array}{c}\text { Biomass } \\
\mathrm{g} / \mathrm{l}\end{array}$ \\
\hline $3^{\text {rd }}$ & 4 & 10.4 & 2 & 9.6 & 1 & 10.8 & 17 & 2 \\
\hline $4^{\text {th }}$ & 5 & 11.6 & 5 & 11.6 & 16.5 & 10.4 & 28 & 1.04 \\
\hline $5^{\text {th }}$ & 6 & 10.6 & 40 & 10 & 10 & 8.8 & 25 & 0.8 \\
\hline $6^{\text {th }}$ & 4 & 11.6 & 6 & 8 & 8 & 8.6 & 8 & 0.68 \\
\hline $7^{\text {th }}$ & 0 & 14.0 & 4 & 0 & 0 & 8.0 & 0 & 0.56 \\
\hline
\end{tabular}


Table 4. Selection of best lipidic substrates for lipase production by $P$. chrysogenum 9

\begin{tabular}{lccc}
\hline \multicolumn{1}{c}{ Inducers } & $\begin{array}{c}\text { Activity, } \\
\mathrm{U} / \mathrm{ml}\end{array}$ & $\begin{array}{c}\text { Biomass, } \\
\mathrm{g} / \mathrm{l}\end{array}$ & $\begin{array}{c}\text { Protein, } \\
\mathrm{mg} / \mathrm{ml}\end{array}$ \\
\hline Control & 0 & 6 & 0.19 \\
Tributyrin & 0 & 2 & 0.12 \\
Tricaprylin & 0 & 1.2 & 0.34 \\
Triolein & 41.0 & 4 & 2.46 \\
Soybean oil & 21.5 & 11.2 & 1.25 \\
Rape oil & 0 & 9.2 & 1.03 \\
Corn oil & 55.0 & 6.8 & 2.80 \\
Olive oil & 41.5 & 8 & 1.28 \\
Oleic acid & 38.0 & 10.4 & 1.64 \\
Caprylic acid & 0 & 0 & 0.30 \\
\hline
\end{tabular}

* Control: basic medium without inducer

by Aspergillus terreus when corn oil was used as an inducer, but at a higher concentration of 2\% (Gulati et al., 1999). In contrast, Penicillium restrictum (Gombert et al., 1998), Penicillium citrinum (Maliszewska and Mastalerz, 1992) and Penicillium wortmanii (Costa and Peralta, 1999) presented the highest lipolytic productivity when incubated with olive oil.

Lipase production depends on several environmental factors, such as nitrogen, carbon and lipid sources and initial $\mathrm{pH}$ of the medium. Various carbohydrates at concentration of $1 \%$ were tested. The results summarized in Table 5 show that among various carbon sources, sucrose proves to be the best carbohydrate for high lipase production, but a low biomass $(72 \mathrm{U} / \mathrm{ml})$. However, the biomass was significantly increased $(16 \mathrm{~g} / \mathrm{l})$ when glucose was added to the medium instead of sucrose. Different sucrose concentrations were tested for lipase production. A significant increase in lipase activity $(72 \mathrm{U} / \mathrm{ml})$ was observed in the presence of $1 \%$ of sucrose (data not shown). In contrast, glucose and starch were the best carbon source for the production of lipase by other Penicillium strains P. citrinum (Maliszewska and Mastalerz, 1992) and P. restrictum (Gombert et al., 1998), relatively.

Table 5. Effect of carbon source on growth and lipase production by $P$. chrysogenum 9

\begin{tabular}{lccl}
\hline $\begin{array}{c}\text { Carbon } \\
\text { source (1\%) }\end{array}$ & $\begin{array}{c}\text { Activity, } \\
\mathrm{U} / \mathrm{ml}\end{array}$ & $\begin{array}{c}\text { Biomass, } \\
\mathrm{g} / \mathrm{l}\end{array}$ & $\begin{array}{c}\text { Protein, } \\
\mathrm{mg} / \mathrm{ml}\end{array}$ \\
\hline Control & 14 & 0.4 & 1.64 \\
Lactose & 16 & 14.4 & 0.6 \\
Maltose & 14 & 14.4 & 0.32 \\
Starch & 20 & 1.2 & 1.32 \\
Sucrose & 72 & 7.6 & 3.13 \\
Xylose & 25 & 15.2 & 0.5 \\
Glucose & 40 & 16 & 0.27 \\
Fructose & 6.5 & 13.6 & 0.43 \\
Galactose & 15 & 15.2 & 0.24 \\
& & &
\end{tabular}

* Control: basic medium without carbohydrate
Different types of organic and inorganic nitrogen sources were tested in order to determine their effect on fungal growth and lipase production. As shown in Table 6 , out of various organic nitrogen sources, urea (concentration of $0.4 \%$ ) was the best nitrogen source for increasing the lipolytic activity in the fungal culture. In this case, the highest enzyme activity $(68 \mathrm{U} / \mathrm{ml})$, but a low biomass $(7.2 \mathrm{~g} / \mathrm{l})$ was observed. This is similar to the report on lipase production by Yarrowia lipolytica strain, where the maximum lipase activity was reached after adding urea as nitrogen source (Corzo and Revah, 1999). Moreover, asparagine was also found to be good nitrogen for lipase activity $(25.5 \mathrm{U} / \mathrm{ml})$, while the lipase production was inhibited with other organic nitrogen sources. Among inorganic nitrogen sources sodium nitrate was found to be the most effective for the lipase production $(63.5 \mathrm{U} / \mathrm{ml})$.

Table 6. Effect of nitrogen source on growth and production of lipase by $P$. chrysogenum 9 (urea at a concentration of $0.4 \%$, others at a concentration of $1 \%$ )

\begin{tabular}{lccc}
\hline $\begin{array}{c}\text { Nitrogen } \\
\text { source }(1 \%)\end{array}$ & $\begin{array}{c}\text { Activity, } \\
\mathrm{U} / \mathrm{ml}\end{array}$ & $\begin{array}{c}\text { Biomass, } \\
\mathrm{g} / \mathrm{l}\end{array}$ & $\begin{array}{c}\text { Protein, } \\
\mathrm{mg} / \mathrm{ml}\end{array}$ \\
\hline Control & 0 & 0.04 & 0.15 \\
Yeast extract & 4 & 11.2 & 2.02 \\
Peptone & 5 & 14.8 & 2.43 \\
Urea & 68 & 7.2 & 2.39 \\
Casein & 6 & 10 & 1.64 \\
Asparagine & 25.5 & 10 & 2.85 \\
$\mathrm{NaNO}_{3}$ & 63.5 & 8.4 & 1.91 \\
$\left(\mathrm{NH}_{4}\right)_{2} \mathrm{HPO}_{4}$ & 0 & 16.8 & 1.23 \\
$\mathrm{NH}_{4} \mathrm{NO}_{3}$ & 0 & 14.8 & 0.18 \\
\hline
\end{tabular}

* Control: basic medium without nitrogen source

The production of lipase was not detected in the culture medium containing ammonium dihydrogen orthophosphate or ammonium nitrate. Lipase production by Cryptococcus sp. S-2 was neither observed on the culture medium containing ammonium nitrate (Kamini et al., 2000). Corzo and Revah (1999) reported ammonium sulfate not to enhance the production of extracellular lipase by Yarrowia lipolytica. Medium without nitrogen source did not induce lipase production or growth of $P$. chrysogenum. According to the results obtained in the following experiments $0.4 \%$ urea was used.

The enzyme secretion is greatly influenced by a change in the initial $\mathrm{pH}$ of medium. To observe the effect of the initial pH of the GKM medium on lipase production, $\mathrm{pH}$ of the medium was varied from 3.0-7.5. As shown in Fig. 1, the maximum extracellular lipase production $(68 \mathrm{U} / \mathrm{ml})$ was achieved at $\mathrm{pH} 6.0$ by $P$. chrysogenum. This result was in accordance with studies on Penicillium citrinum (Maliszewska and Mastalerz, 1992) and Candida lipolytica (Pereira and Rocha, 1997). Lipase activity from P. chrysogenum was not observed when the initial pHs of the medium were 3.0-5.0. The lowest lipase activity was obtained when the initial $\mathrm{pH}$ was adjusted to 7.5 (5 U/ml). The 


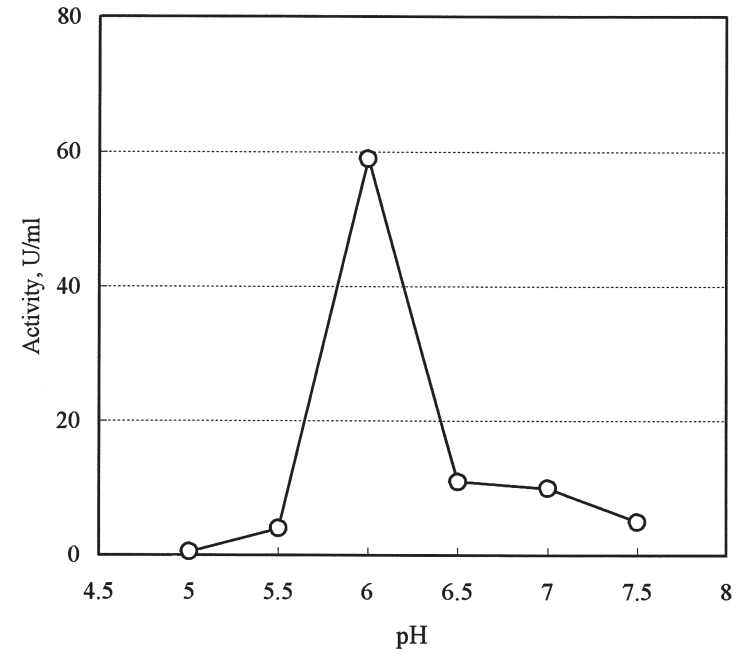

Fig. 1. Effect of initial $\mathrm{pH}$ on $P$. chrysogenum lipase production.

lipase from other Penicillium strains - P. cyclopium (Vanot et al., 2002) and P. restrictum (Gombert et al., 1998) showed the highest activity when the initial $\mathrm{pH}$ of the media were adjusted to 5.0. Excretion of lipase by Rhodotorula glutinis (Papaparaskevas et al., 1992) was the highest at initial $\mathrm{pH} 8.0$.

The enzyme activity is determined by the reaction conditions, such as temperature, $\mathrm{pH}$ and presence of inhibitory compounds. The extracellular lipase of $P$. chrysogenum was studied regarding the optimum of both $\mathrm{pH}$ and temperature according to different substrates. As it can be seen in Fig. 2, the optimal activity for lipase was found in the range of temperature $30-37^{\circ} \mathrm{C}$. Optimum temperature depends on the substrate used in the reaction. The highest activity of lipase with tributyrin as a substrate was observed at $30^{\circ} \mathrm{C}$. Therefore, this substrate was selected to be the best for lipase activity of extracellular lipase from Penicillium chrysogenum.

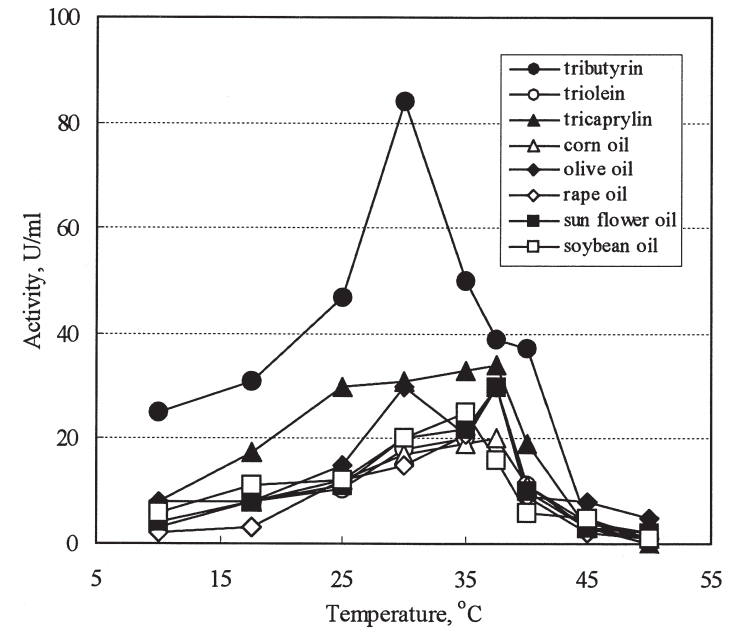

Fig. 2. Effect of reaction temperature on lipase activity according to different substrates Lipase activity was estimated at temperature in the range of $20-80^{\circ} \mathrm{C}$.
The optimal $\mathrm{pH}$ for lipase activity was found in the range of 5.0-7.0 and depends mainly on the kind of substrates tested in this experiment. In the presence of synthetic substrates (tributyrin, tricaprylin and triolein) the maximum activity of lipase was found at pH 7.0 (Fig. 3a). However, in the presence of natural substrates (oils), the maximum lipolytic activity was achieved at $\mathrm{pH}$ 5.0 (Fig. 3b). Similar results have not been found by now in available literature concerning this protein. Therefore, the mechanism of such reactions is still unknown. The enzyme from Penicillium cyclopium (Vanot et al., 2002) exhibited a maximum activity at $\mathrm{pH}$ 7.0 at $50^{\circ} \mathrm{C}$. Lipase from P. chrysogenum (Ferrer et al., 2000) showed the greatest activity at $\mathrm{pH} 7.9-8.1$ and $45^{\circ} \mathrm{C}$. These results were in accordance with studies on Penicillium citrinum (Maliszewska and Mastalerz, 1992). The importance of the data presented here point to the possibility of obtaining an active lipase producer from psychrotrophic microorganisms. Penicillium chrysogenum as the fungus having the highest lipolytic activity will be great interest in biotechnological research.
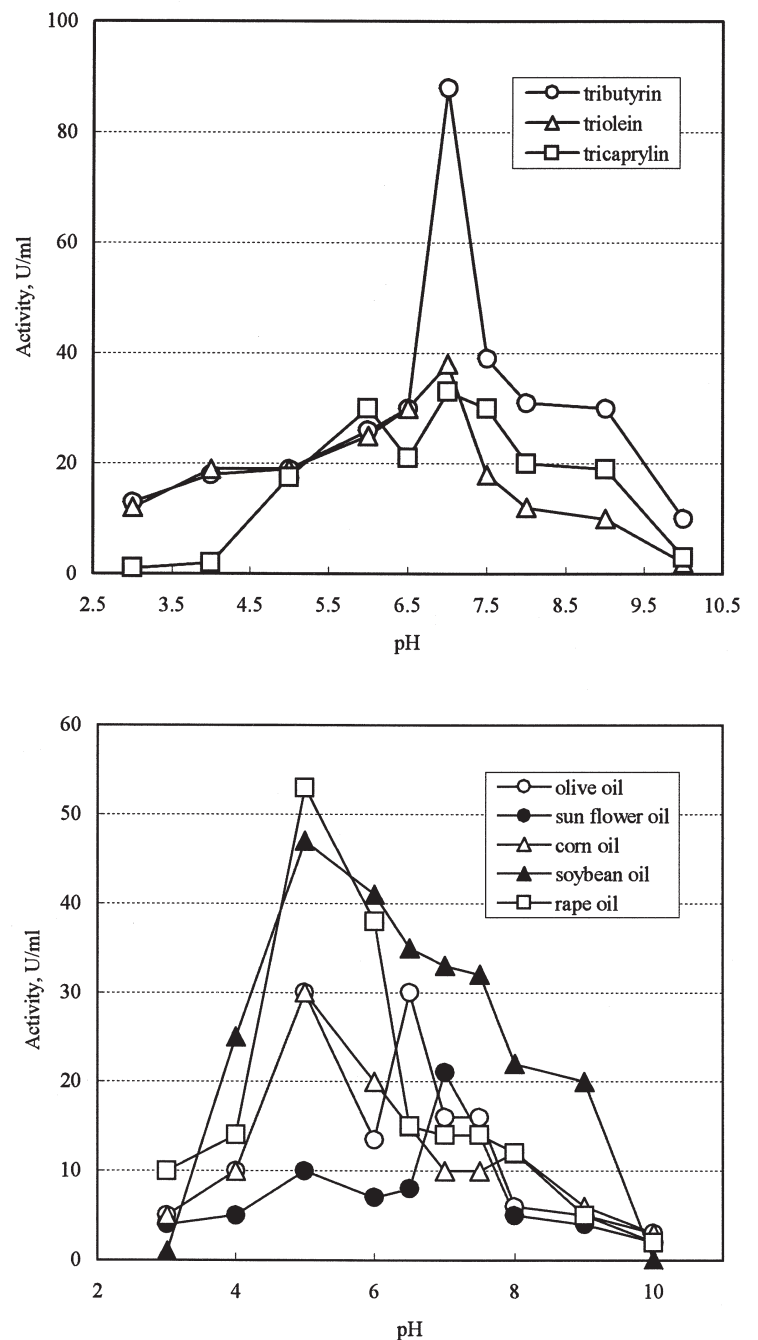

Fig. 3. Activity of lipase from $P$. chrysogenum against synthetic substrates (a, above) or natural substrates (b, under) depending on $\mathrm{pH}$. Lipase activity was estimated at $\mathrm{pH}$ values in the range of $\mathrm{pH} 3.0-10.0$. 


\section{REFERENCES}

Cardenas, F., E. Alvarez, M. S. de Castro-Alvarez, J. M. Sanchez-Montero, M. Valmaseda, S. Elson and J. V. Sinisterra 2001 Screening and catalytic activity in organic synthesis of novel fungal and yeast lipases. J. Mol. Catal. B: Enzymatic., 14: $111-123$

Corzo, G. and S. Revah 1999 Production and characteristics of the lipase from Yarrowia lipolytica 681. Biores. Technol., 70: $173-180$

Costa, M. M. and R. Peralta 1999 Production of lipase by soil fungi and partial characterization of lipase from a selected strain (Penicillium wortmanii). J. Basic. Microbiol., 39: $11-15$

Domsch, K. H., W. Gamsch and T. H. Anderson 1980 Compendium of soil fungi. Vol. 1, Academic Press, London

Feller, G. M. Thirty and C. Gerday 1991 Cloning and expression in Escherichia coli of three lipase-encoding genes from the psychrotrophic antarctic strain Moraxella TA 44. Gene., 102: 111-115

Ferrer, M., J. F. Plou, O. M. Nuero, F. Reyes and A. Ballesteros 2000 Purification and properties of a lipase from Penicillium chrysogenum isolated from industrial wastes. $J$. Chem. Technol. Biotechnol., 75: 569-576

Gombert, A. K., A. L. Pinto, L. R. Castilho and D. M. G. Freire 1998 Lipase production by Penicillium restrictum in solid-state fermentation using babassu oil cake as substrate. Process. Biochem., 35: 85-90

Gulati, R. R. K. Saxena, R. Gupta, R. P. Yadav and W. S. Davidson 1999 Parametric optimisation of Aspergillus terreus lipase production and its potential in ester synthesis. Process Biochem., 35: 459-464

Isobe, K., K. Nokihara, S. Yamaguchi, T. Mase and R. D. Schmid 1992 Crystallization and characterization of monoacylglycerol and diacylglycerol lipase from Penicillium camembertii. Eur. J. Biochem., 203: 233-237

Kamini, N. R., T. Fujii, T. Kurosu and H. Iefuji 2000 Production, purification and characterization of an extracellular lipase from the yeast, Cryptococcus sp. S-2. Process Biochem., $\mathbf{3 6}$ : 317-324

Land, C. J., Z. G. Banhidi and A. C. Albertsson 1987 Cold-tol- erant (psychrotrophic) moulds and blue stain fungi from softwood in Sweden. Growth rates in relation to $\mathrm{pH}$ and temperature. Nord. J. Botany, 7: 97-106

Lowry, O. H., N. J. Rosebrough, A. L. Farr and R. J. Randall 1951 Protein measurement with the Folin phenol reagent. J. Biol. Chem., 193: 265-275

Ludlow, J. M. and D. S. Clark 1991 Engineering considerations for the application of extremophiles in biotechnology. Crit. Rev. Biotechnol., 10: 321-345

Maliszewska, J. and P. Mastalerz 1992 Production and some properties of lipase from Penicillium citrinum. Enzyme Microb. Technol., 14: 190-193

Margesin, R. and F. Schinner 1994 Properties and cold adapted microorganisms and their potential role in biotechnology. $J$. Biotechnol., 33: 1-14

Onions, A. H. S. and B. L. Brady 1987 Taxonomy of Penicillium and Acremonium. In Biotechnology Handbooks ed. Atkinson T, Sherwood RF. Plenum Press New York

Papaparaskevas, D., P. Christakopoulos, D. Kekos and J. B. Macris 1992 Optimizing production of extracellular lipase from Rhodotorula glutinis. Biotechnol. Lett., 14: 397-402

Pereira-Meirelles, F. V. and M. H. Rocha-Leao 1997 A stable lipase from Candida lipolytica. Cultivation, conditions and crude enzyme characteristics. Appl. Biochem. Biotechnol., 63/65: $73-85$

Prins, R. A., W. de Vrij, J. C. Gottschal and T. A. Hansen 1990 Adaptation of microorganisms to extreme environments. FEMS Microbiol. Rev., 75: 103-104

Sarkar, S., B. Sreekanth, S. Kant, R. Banerjae and B. C. Bhattacharyya 1998 Production and optimization of microbial lipase. Bioproc. Engin., 19: 29-32

Sokolovska, I., C. Albasi, J. P. Riba and V. Bales 1998 Production of extracellular lipase by Candida cylindracea CBS 6330. Bioprocess Engin., 19: 179-186

Stöklein, W., H. Sztajer, U. Menge and R. D. Schmid 1993 Purification and properties of a lipase from Penicillium expansum. Biochim. Biophys. Acta, 1168: 181-189

Vanot, G., D. Valerie, M. C. Giuhem, R. Phen Tan Luu and L. C. Comeau 2002 Maximizing production of Penicillium cyclopium partial acylglycerol lipase. Appl. Microbiol. Biotechnol., 60: 417-419 